\title{
Status of Using Assistive Technology by Students with Disabilities at Sultan Qaboos University
}

\author{
Wajeha Al-Ani, Ali Al Musawi, Widad Al-Hashmi, Balqees Al-Saddi \\ Sultan Qaboos University
}

\begin{abstract}
This study is conducted to explore students with disabilities use of Assistive Technology in learning at Sultan Qaboos University (SQU) in Oman. To achieve this objective, a descriptive approach was followed by developing a questionnaire that includes five domains: learning achievement, learning motivation, sharing and communication, critical thinking, and self-esteem. The questionnaire was tested to ensure its validity and reliability, and was applied to a study sample of 60 students (27 males, and 33 females), representing 83\% of the total population. The findings show that students perceive Assistive Technology positively, as it develops their abilities to search for information, provides them with more opportunities to collaborate and share ideas and information with their peers, motivates them to learn, and allows them to develop their senses of questioning and investigating using more creativity and problem-solving skills. In light of these findings, the study suggests some recommendations.
\end{abstract}

\section{Introduction}

Limited attention is given to people with special needs from stakeholders and decision makers. AlSukran [1] discusses the current changes and developments with regard to people with disabilities in order to highlight the challenges they encounter, and to propose actions to ensure that their rights are protected. He notes that people with special needs are often overlooked, disallowed from training and programs, and are not provided with clear policies and plans to fulfill their needs. He adds that they face disrespect in all domains. In addition, they are not provided with intensive care, education, rehabilitation, inclusion and life facilities. Moreover, people with special needs not only do not receive their right to a job, they also do not have specialized institutions, nor do they receive appropriate educational, psychological and medical treatment due to limited funding. Al-
Hosawi [2] stresses the importance of self-preparation of people with disabilities for society and adaptation to it. He emphasizes that they should be aware of their abilities and potentials, and develop self-confidence to be productive in society. Therefore, people with disabilities need to be trained and enrolled in a rehabilitation program to be able to achieve social qualification.

\section{Theoretical Framework}

This section reviews recent literature on students with disabilities learning, particularly in areas related to assistive technology and its integration. It also briefs research evidence about the effectiveness of assistive technology concerning the study variables i.e. gender and self-esteem. It sheds light on the study context in the Arab and Omani settings.

\subsection{Technology Integration in Students with Disabilities' Learning}

Technology develops rapidly due to the changing and developing needs of people and societies [3], including those of people with special needs, to provide them with the assistance needed for life and work skills. Several researches have conducted content analysis of previous works related to the use of technologies in education. They have focused on the classification of technology research types, analysis and data collection procedures, and the different statistical methods and strategies implemented, in order to form a deeper understanding of the development and trends of implementing technologies in educating students with disabilities [4], [5].

Some of the advantages of using technology to teach students with disabilities include providing them with opportunities to share discussions and communicate, encouraging self-study, giving learners immediate feedback, meeting requirements for 
individual differences, and offering varied and alternative learning resources that fulfill learners' learning needs due to the regularly updated content [6].

\subsection{Assistive Technology}

The implementation of technology in the learning process of students with disabilities is referred to as 'Assistive Technology' (AT), which is a combination of basic tools to assist any student with a disability to compete with normal students in the class. It is deemed necessary for providing the best learning experience for students with disabilities [7].

Many expressions are used in addition to assistive technology, such as educational technologies, assistive educational tools (auditory and visual), educational tools, educational media, and assistive educational technology. However, they differ in their content and purpose. The US Department of Education defines AT as "any device or produced system that is utilized to increase, maintain or improve the functionality of disabled people" USDOE (1990; as cited in [8]). The Individuals with Disabilities Education Act of the United States identifies AT as any material, device or produced system, or any tool amended or produced upon request to increase its functionality for people with disabilities. These devices could be provided by the school itself or by specialized organizations where various types of assistive technology exist and which students with disabilities could use. Some of these devices are low-tech, such as an on-off recording switch, or high-tech devices that include advanced computers and other devices that enhance hearing, vision and communication [8]. Most professionals in this field agree that AT refers to any educational tool that helps understanding the content, though it is not electronic. Thus, in this study, AT is defined as all the tools and basic programs in the educational process used by students with disabilities to help them access necessary knowledge and skills in the teaching and learning process and better achieve their goals.

Assistive technology was introduced to satisfy the basic and necessary needs of people with special needs in order to ease life tasks and enable them to be productive in all life domains. During the last forty years, assistive technology has added feasibility to the lifestyle, education, and training and rehabilitation of people with special needs. For example, it assists them in the fields of reading, learning, writing, using tools (e.g. kitchen tools) and enables them to complete tasks independently [3].

\subsection{Types of Assistive Technology}

Al-Khafaf [3] lists seven types of assistive technology. They include position (posture and transportation), mobility (ability to do anything from easy to difficult and to move in larger environments), communication, computer, playing, adaptive, and instructional technology. It is important to choose the tools that best help and match the needs of the disabled. The technological device should align with the characteristics of the person in order to be adaptive. Training is necessary for people with special needs to be able to use technology effectively.

\subsection{Using Assistive Technology in Learning by Students with Disabilities}

The importance of using assistive technology has been increasing in the last few decades, and has played a major role in teaching all students, especially students with disabilities, as it helps them overcome independence difficulties, facilitates social communication and improves their understanding and applicability of life skills. AT is vital for the educational process because it paves the way for students with disabilities to achieve their aspired learning goals through reinforcement of the educational content with varied knowledge, experiences, and contexts. It is most important for students with disabilities for it eases their adaptation to new teaching strategies that use assistive educational technologies and multimedia to transfer information to students. Researchers have long investigated the use of assistive technology in the learning process.

Alnahdi [9] believes that the integration of technology in special education facilitates the accomplishment of academic tasks for students with disabilities, some of which are classroom discussions and independent learning. The researcher provides universal principles for delivering education to students with disabilities called the Universal Design for Learning (UDL). It is referred to as a system that supports the learning of all students in terms of curriculum design and development, and integration of assistive technology into the curriculum for students with disabilities. They include 1) equitable use; 2) flexibility in use; 3) simple and intuitive use; 4) perceptible information; 5) tolerance for error; 6) low physical effort; 7) size and space for approach and use appropriate (Trace Center, 1995 as cited in [9]). The UDL gives students with disabilities their right of 
receiving appropriate education by utilizing assistive means to help them reach their academic goals.

The environment where students with disabilities study should be accessible to support assistive technology, and the curriculum should be developed to align with available assistive technology. Examples of accessible technologies include web pages that help students with low reading skills to receive required information, software or programs that enable students to cooperate with classmates to complete tasks, and accessible telephones to facilitate communication regardless of the disabilities (Burgstahler, 2003 as cite in [9]). In addition, Raskind (1994 cited in [9]) lists some technologies that could assist students with disabilities to improve different skills: word processors, spell checking, outlining (brainstorming) and proofreading programs, speech recognition software, abbreviation expanders, speech synthesis, optical character recognition systems, Free-Form Databases, as well as talking calculators. Ahmed [10] supports the role of assistive technology discussed by [9], and provides a list of the learning skills and disabilities with the appropriate assistive technology in Table 1.

Ahmed [10] conducted a study to uncover the factors that cause the lack of assistive technology in special education, and to explore education professionals' beliefs about the integration of assistive technology into special education. This study was intended to break the gap between general ideas about special education and real practice. The researcher believes that educators need to realize how this connection could have a significant impact on the learning process of students with disabilities. Ahmed emphasizes the role of technology in improving students with disabilities' learning, clarifying its benefits in enabling those students to overcome academic challenges. In order to gain a thorough understanding of special education, the researcher conducted a pilot study to reveal the public opinions towards the importance of technology in special education. Ahmed shed light on students with disabilities' rights to use technology and enjoy a better learning experience. He states that assistive technology positively influences the academic performance of students with disabilities, which helps them become more independent (as revealed by [11]), and improves their quality of life. Results advocate the use of assistive technology in special education. Ahmed revealed that the majority of participants did not use assistive technology in their classes, although most of them were allowed to use it in the classroom.
The participants provided a list of advantages for the integration of assistive technology into special education. They believe that assistive technology has a positive influence on students' academic performance, helps students achieve challenging tasks and overcome academic difficulties, provides students with the opportunity to receive the learning assistance they require, and enables them to be more independent [9] [10].

They stress that assistive technology should be available for students who need it in order to guarantee fair education, in addition to training them to use it, which supports views from [10]. Most of the participants agree that assistive technology should be provided for students, and that the funding and cost of assistive technology are the major obstacles for its availability. Despite the strong tendency towards using assistive technology, results from this study show that teachers are not familiar with the benefits of assistive technology for students with disabilities. This contradicts results from [11], where teachers are familiar with the use of technology.

\subsection{Self-esteem and Students with Disabilities}

Self-esteem leads to positive attitudes toward life and learning. Given this significance of self-esteem to well-being and education, a number of scales have been designed to measure individuals' judgement about their life. Rosenberg [12] proposed the Rosenberg Self-Esteem Scale.

It is a students' satisfaction scale to measure their ability to make judgements about themselves, their feelings in terms of self-respect and self-accept, and their evaluation of their own abilities, characteristics and behaviors. He claims that these factors appear in childhood and are in play throughout a person's life span, usually affected by people and surrounding environments.

Self-esteem motivates students to perform tasks, learn, and develop personality to endure life challenges. It is believed to increase mental health and feelings of happiness, whereas its absence results in the opposite. Low self-esteem is a result of negative judgements on persons' behaviors, seeing themselves failures and being unqualified. Self-esteem can be maximized through self-respect and self-appreciation.

Abu Daoud and Al Khateeb [13] looked at the relationship between life satisfaction, hope, and selfdetermination and their effect on adolescents with disabilities. 
Table 1. Use of assistive technology in students with disabilities' learning

\begin{tabular}{|c|c|c|}
\hline $\begin{array}{l}\text { Category/ area of } \\
\text { function }\end{array}$ & Assistive technology applications & $\begin{array}{l}\text { Need and relevance in classroom } \\
\text { learning }\end{array}$ \\
\hline Reading & $\begin{array}{l}\text { Electronic books, Book adapted for page turning, } \\
\text { Single word scanners, Predictable texts, Tabs, } \\
\text { Talking electronic devices/software, Speech } \\
\text { Software }\end{array}$ & $\begin{array}{l}\text { For students having difficulty in } \\
\text { reading and understanding written text } \\
\text { and in paying attention to the reading } \\
\text { assigned }\end{array}$ \\
\hline Writing & $\begin{array}{l}\text { Pen/Pencil grips, Templates, Word processors, } \\
\text { Word card/book/wall, software, Spelling/Grammar } \\
\text { checker, Adapted papers }\end{array}$ & $\begin{array}{l}\text { For students having problem in writing } \\
\text { or composition }\end{array}$ \\
\hline Math & $\begin{array}{l}\text { Calculators, Talking Clocks, Enlarged Worksheets, } \\
\text { Voice Output Measuring Devices, Scientific } \\
\text { Calculators }\end{array}$ & $\begin{array}{l}\text { For students having computational } \\
\text { problems and confusion, and finding it } \\
\text { difficult to perform well in math lessons }\end{array}$ \\
\hline Vision & $\begin{array}{l}\text { Eye glasses, Magnifier, Screen Magnification, } \\
\text { Screen Reader, Braille Large Print Books, CCTV, } \\
\text { Audio Lesson Tapes }\end{array}$ & $\begin{array}{l}\text { For students who have difficulty in } \\
\text { seeing or lack complete vision }\end{array}$ \\
\hline Hearing & $\begin{array}{l}\text { Hearing Aids, Pen and paper, Signaling Devices, } \\
\text { Closed Captioning }\end{array}$ & $\begin{array}{l}\text { For students who have difficulty in } \\
\text { hearing or are absolutely hearing } \\
\text { impaired }\end{array}$ \\
\hline Computer access & $\begin{array}{l}\text { Word prediction, Alternative Keyboards, Pointing } \\
\text { Option, Switches, Voice recognition software }\end{array}$ & $\begin{array}{l}\text { For students finding it difficult to } \\
\text { access a computer in its standard form } \\
\text { and have difficulty in performing } \\
\text { academic tasks }\end{array}$ \\
\hline $\begin{array}{l}\text { Augmentative/Alternative } \\
\text { Communication }\end{array}$ & $\begin{array}{l}\text { Communication Board, Device with speech } \\
\text { synthesis for typing, Eye gaze board/ frame, Voice } \\
\text { output device }\end{array}$ & $\begin{array}{l}\text { For students having problems in } \\
\text { comprehension of language, and } \\
\text { lacking the ability to express it, or are } \\
\text { unclear in speech and demonstrate } \\
\text { delayed expressive language }\end{array}$ \\
\hline $\begin{array}{l}\text { Learning Disability and } \\
\text { Attention Deficit } \\
\text { Hyperactivity Disorder } \\
\text { (ADHD) }\end{array}$ & $\begin{array}{l}\text { Use of applications/devices depending upon the } \\
\text { degree of disability/difficulty, in the area of reading } \\
\text { and writing (Dyslexia), hand-eye coordination, } \\
\text { written expression and composition (Dysgraphia), } \\
\text { difficulty in motor skills, Coordination (Dyspraxia), } \\
\text { Math (Dyscalculia) and Attention (ADHD) like - } \\
\text { Talking electronic devices, Calculators, Electric } \\
\text { Organizers, Highlighters, Pencil Grips, Post-its, } \\
\text { Computers, Spelling/Grammar Checker, Electronic } \\
\text { Organizers, } \\
\text { Recorded materials, Hand held Scanners, Print or } \\
\text { picture schedule, Electronic Diaries etc. }\end{array}$ & $\begin{array}{l}\text { For Students having problem in } \\
\text { language development, reading and } \\
\text { writing (Dyslexia), hand-eye } \\
\text { coordination, written expression and } \\
\text { composition (Dysgraphia), difficulty in } \\
\text { fine motor skills, coordination } \\
\text { (Dyspraxia), Math (Dyscalculia), and } \\
\text { ADHD. }\end{array}$ \\
\hline
\end{tabular}

Source: ([10]; p. 65-67)

The researchers note that low life satisfaction and selfesteem are common problems with people with disabilities worldwide. This study addresses the variables that could affect persons with special needs, and therefore sets up plans to improve their lives. Hope, for example, is a significant factor that contributes to the academic quality of a student with special needs, which therefore would lead to academic achievements. Abu Daoud and Al Khateeb used three scales to measure life satisfaction and help understand adolescents' attitudes and self-esteemMultidimensional Life Satisfaction Scale, the ARC's Self-Determination Scale, and the Children's Hope Scale. Results show that adolescent students with disabilities are highly satisfied with their lives, selves, families, friends, and school. The researchers assume that this satisfaction is related to religious beliefs, role of family, and support from friends. Results also show that an increase in self-determination entails an increase in the life satisfaction of adolescent students 
with disabilities. Researchers point out those selfdetermined students could make their own decisions, which therefore helps them feel satisfied. Consequently, they are able to make good relationships with family and friends, and they do not feel forced to make specific decisions. Another result is that higher levels of hope increase satisfaction. If hope were lost, students with disabilities would face more difficulties in progressing academically.

\subsection{The Omani Context}

The report issued by the Directorate General of Social Welfare [14] indicates that the Sultanate of Oman is making every effort to care for and attend to the needs of persons with disability; specially after issuing the Royal Decree No. 121/2008 relating to the Sultanate's ratification of the Convention on the Rights of Persons with Disabilities (CRPD). The Convention defines persons with specials needs as "all those who are suffering from long-term impairments which hinder them from comprehensively and effectively to equally participate in the society with others. Such impairments can be physical, mental, cognitive and sensory." The Ministry is implementing several programs for providing comprehensive and integrated services for persons with special needs in the Sultanate (13026 persons with special needs). These services are provided through different centers; such as, the Care and Rehabilitation Center of the Disabled in Al Khoudh and the Care Home for Children with Disabilities in Muscat. Also, the Ministry of Education provides services for students with special needs in $\mathrm{Al}$ Amal School for the Deaf, Al Fikriyah School for Students with Intellectual Disabilities, Omar bin AlKhattab Institute for the Blind, and the inclusion program in public schools. Furthermore, people with special needs are provided with social, medical, educational, housing services, and job opportunities. They are also enjoying support of the Ministry of Sports, which engages them in social, sports and cultural activities. Al-Ani [15] found that the educational system in Oman has different names and methods for the Alternative Education, like the ones hereinbefore. Al-Ani suggested a comprehensive implementation of Alternative Education, presenting it as an inclusive model for the education for all philosophy, because it can harmonize all learners, including students with disabilities, with the targeted educational programs that fit with their needs and potentials as that service the country future trends.
Based on the significance of Assistive Educational Technology in the learning process, educational means have became a major cornerstone in the educational process. Thus, they cannot be relinquished in learning situations. Due to this significance, Sultan Qaboos University (SQU) has established the Students with Disabilities Affairs Department in 2009 to be an ideal model for the inclusion program of students with disabilities into university life. It ensures their effective participation in the university society where their abilities are fostered and university life opportunities are maximized through providing them with versatile academic and social services. Students with disabilities in SQU include those with health and physical impairment, visual impairment, hearing impairment (students with low hearing level), chronic diseases, communication disorder, learning difficulties, psychological disorder, and students suffering from temporary disabilities as a result of a disease or an accident. The department, in cooperation with all employees and all departments working with students with disabilities, is opening up the university environment for them by providing optimal services and advanced technology/software devices, including wheelchairs, braille devices, etc., that enable these students to achieve the best learning performance throughout their university life. Moreover, the department trains students with disabilities to use computers and the internet by utilizing audio programs and various devices. In addition, it coordinates with different departments to provide some devices and technologies that are not available at the university.

When discussing the reality of care provided to students with disabilities at SQU, which is the focus of this study, data shows that the university is striving to provide them with comprehensive care as outlined in the inclusion strategy offered for this category of students. This data was collected from two interviews conducted with the head of the Department of Students with Disabilities Affairs on 20-2-2011 and 7-3-2019 at the Students Affairs Deanship. The admission conditions for this category of students is not different compared with normal students. In this context, [16] carried out a descriptive study on 28 male and 12 female SQU students having different visual and physical impairments. Alqaryouti [16] has indicated statistically significant differences related to students' perspectives towards the obstacles hindering them from inclusion due to their disabilities. Moreover, it shows that there are statistically significant differences for the interaction between the impairment level and gender. 
The learning services are provided for each category of these students as per their disability case, as well as medical care, medical facilities, housing, and continuous daily supervision. Since the Department of Students with disabilities Affairs is quite new, it has to cooperate with the Legal Affairs Department at SQU to formulate the regulations and laws pertained to this category of students in accordance with their rights and duties. The department would also prepare a cumulative profile for each student, and would establish a follow-up postgraduation program. Statistics show that there are 67 male and female students with special needs majoring in different field in all SQU colleges, as shown in Table 2.

Table 2. Students with disabilities at SQU

\begin{tabular}{|c|c|c|c|c|c|c|c|c|}
\hline \multirow[t]{2}{*}{ College } & \multicolumn{2}{|c|}{ Visual } & \multicolumn{2}{|c|}{$\begin{array}{l}\text { Physic } \\
\text { al }\end{array}$} & \multicolumn{2}{|c|}{ Audio } & \multicolumn{2}{|c|}{ Others } \\
\hline & $\mathrm{M}$ & $\mathrm{F}$ & $\mathrm{M}$ & $\mathrm{F}$ & $\mathrm{M}$ & $\mathrm{F}$ & M & $\mathrm{F}$ \\
\hline $\begin{array}{lr}\text { College } & \text { of } \\
\text { Arts and } \\
\text { Social } \\
\text { Sciences }\end{array}$ & 3 & 5 & $\begin{array}{l}1 \\
7\end{array}$ & 21 & & 1 & 1 & \\
\hline $\begin{array}{l}\text { College of } \\
\text { Economics }\end{array}$ & 4 & & & & 1 & & & \\
\hline $\begin{array}{l}\text { College of } \\
\text { Medicine }\end{array}$ & & & 1 & & & & & \\
\hline $\begin{array}{l}\text { College of } \\
\text { Agriculture } \\
\text { and Marine } \\
\text { Sciences }\end{array}$ & & 1 & 1 & & & & & \\
\hline $\begin{array}{l}\text { College of } \\
\text { Engineering }\end{array}$ & 1 & & & & & & & \\
\hline $\begin{array}{l}\text { College of } \\
\text { Science }\end{array}$ & 3 & 1 & & & 1 & & & \\
\hline $\begin{array}{l}\text { College of } \\
\text { Low }\end{array}$ & 1 & & 1 & & & & 1 & \\
\hline $\begin{array}{l}\text { College of } \\
\text { Education }\end{array}$ & & & 1 & 1 & & & & \\
\hline \multirow[t]{3}{*}{ Total } & $\begin{array}{l}1 \\
2 \\
\end{array}$ & 7 & $\begin{array}{l}2 \\
1 \\
\end{array}$ & 22 & 2 & 1 & 2 & - \\
\hline & \multicolumn{2}{|l|}{19} & \multicolumn{2}{|c|}{43} & \multicolumn{2}{|l|}{3} & \multicolumn{2}{|l|}{2} \\
\hline & \multicolumn{8}{|c|}{67} \\
\hline
\end{tabular}

Students with special needs have made several achievements in SQU. For example, the team of students with visual impairment won the first place in the Oman Target Ball Championship a number of art galleries were held by a female student and a number of students participated in the Student Companies Competition run by Injaz Oman. Some students scored high academic grades; for example, the top of English cohort, and the highest percentage in high school $(99 \%)$.

Studies have indicated the positive impact of employing technology on improving students' academic achievement, as well as positive attitudes among them towards the use of technology in the Omani educational environment [17] [18] [19]. AlRabeei and Al-Oufi [20] conducted a study on 26 faculty members at Sohar University and on 70 male and female teachers in pre-university education in Oman, with an emphasis on the use of teaching technologies for students with disabilities. They circulated a questionnaire that includes 30 educational objectives expected to be achieved by distance education, and were divided into three main dimensions: outstanding learners, learners with disabilities, and students with learning difficulties. The study shows that distance education programs contribute to the achievement of some educational objectives for outstanding learners at a moderate level, while learners with disabilities and students with learning difficulties scored 'poor' for the statement of "fulfillment of educational objectives." The reason for this students with disabilities low achievement level is attributed to the difficulty of dealing with modern technologies in distance education programs. El-Shourbagi [21] also conducted a descriptive study on 100 teachers of students with disabilities in inclusive classes in Omani basic education schools. El-Shourbagi developed data collection tools with an emphasis on psychometric properties. Findings show that teachers assume that the use of technology, such as robot applications, can facilitate the participation of students with disabilities parents in the school in terms of the inclusion program and follow-up of academic performance.

Al Qaryouti and Al Shukaili [22] discussed the trend of inclusion of students with disabilities into normal students' classes. They point out that inclusion has been implemented widely and should be accepted by all parties in an institution for it to be successful. They add that successful inclusion needs to satisfy the needs of students with disabilities, which include educational changes, curriculum development, evaluation criteria, technical support, building facilities, technological equipment, and other supportive facilities. On this basis, [22] attempted to explore SQU students' attitudes towards the inclusion of students with disabilities. They found that, generally, female students show positive attitudes towards the inclusion of the disabled than male 
students. They have also found that colleges of science accept inclusion more than those in the humanities.

A number of studies in the field of integrating assistive technology into special needs programs were conducted in the Omani context, involving Omani students with disabilities in Omani schools. In this context, [23] aimed to explore the challenges that students with disabilities encounter when using elearning from the perspective of teachers in Omani schools. Given the nature of this research and its objectives, the descriptive analytical approach was adopted to review and analyze Arabic and foreign literature related to the use of e-learning in schools, in addition to the discussions conducted with some experts concerned with designing and developing elearning curriculum for students with disabilities which are based on utilizing e-learning. Such discussions help to reveal the challenges the students with disabilities face when using e-learning in the basic education schools in Oman. A field study was applied on a random sample of Cycle one and Cycle two teachers in three Omani governorates. An initial four-dimension questionnaire was developed to identify the challenges of using e-learning (human, technological, educational or administrative) in the selected schools. The questionnaire was prepared in three stages including: validating it by experts in the fields of curricula and teaching methods of learning difficulties; special education; and teaching and learning technology, piloting it for validity and reliability, and finally administering it to the selected sample. Data analysis included calculating the frequency of responses for each statement in the questionnaire, followed by the application of Chisquared test. Results indicate statistically significant differences (0.05) between the observed frequencies and expected frequencies related to the statement that identifies e-learning challenges. Based on this result, a list of e-learning challenges facing students with disabilities in Omani schools was developed.

Unlike Ammar [23] who looked at teachers' perspectives, [24] sought to identify the perceptions of parents of students with learning difficulties about the outcomes of using modern technology in teaching learning difficulties classes in Omani Cycle One schools. El-Shourbagi [21] adopted the qualitative approach by conducting interviews with 15 families of children involved in learning difficulties programs in Muscat Governorate. The respondents focused on three main dimensions: learner-related outcomes (increase of student motivation and development of self-learning skills), and teacher-related outcomes (reducing the workload and helping them to take into account individual difference). The third dimension focused on the negative aspects of using modern technology in leaning difficulties classes (the need for a technician, the need for sufficient time for the teacher to research and prepare, and the inability of the teacher to make the best use of available technologies). The study suggested significant recommendations for schools, including reallocation of the budget to allow the best use of available technologies, the need to provide teachers with technical skillsets enhancement not only knowledge of the subjects, in addition to the development of electronic teaching methods to be used with the students.

Al Alawi [24] have shifted to the integration of technological devices in teaching students with disabilities. The researcher designed a teaching program based on the flipped classroom strategy via smartphones to measure its effect on the academic achievement of grade 8 blind Omani students, implementing a semi-experimental approach. The experimental group consisted of 8 female taught using the flipped classroom strategy via smartphones, and the control group consisted of 7 students taught using the traditional method. A number of data collection tools were developed, namely, a cognitive test that tests the skills of using the web and search engines among blind students, a rubric of the skillful performance associated with the use of WhatsApp application, and an achievement test including questions of multiple choice and completion. The last tool is a teacher guide with a detailed theoretical framework of the flipped classroom strategy and instructions on how to employ it on smartphones through WhatsApp. Additionally, the teacher guide provided a description of the practical part, including the objectives and teaching plans and recorded audio clips by the teacher about the main points discussed in the class for the fully blind students, with voice and image for the partially blind students. Video filming (ready-made or prepared by the teacher) related to the lesson was also incorporated through WhatsApp, in addition to activities handouts to identify their effectiveness in improving the achievement level of the blind students in Social Studies subject. All students were provided with smartphones to achieve the purpose of the study. The strategy was designed on smartphones throughout five stages: analysis, design, production, development, evaluation, and implementation. Findings reveal the effectiveness of the program in improving the academic achievement level of blind students. It was concluded that the use 
of such strategies via smartphones paves the way to enhancing the level of students' achievement through emphasis of concepts, lessons, ease of understanding and remembrance, making connections between different information, as well as the possibility of referring back to videos and audios at any time. The researcher recommends adapting the flipped classroom strategy through different technologies suitable for blind students enrolled in different grades and academic levels, as well as in other curricula. Moreover, she suggests designing courses with modules and activities inspired by the flipped classroom strategy, and training and encouraging teachers to use this strategy, as proven effective in the educational process.

Similar to [24], [25] aimed to design an interactive module on the human body via tablets for grade 5 Omani students with hearing disabilities. The analytical approach was adopted to analyze the content of the hard-copy curriculum and to build a unit according to the standards and specifications that fit with this category of students. The unit was tested on one group of 14 male and 12 female students throughout 7 weeks at Al-Amal School for the Deaf. To achieve the purpose of the study, the teacher's guide of the interactive module was designed, supportive programs were added to the interactive module, and each student was equipped with a tablet. The module consists of a classroom management application, an interactive book application, and supportive applications within which simplification of the human body with three-dimensional media; the use of augmented reality technology and other educational games are integrated. Data analysis indicats a significant impact of the interactive module on the students with hearing impairment attitudes towards science. The study identified a number of characteristics that distinguish the hearing-impaired students' learning of science. Based on the above results, the study recommends the design of special curricula for students with hearing impairment, taking into account the criteria to be met, in accordance with the limits of hearing disabilities for different age groups.

Al-Shizawi [26] examined the impact of using smartboards on the academic achievement of students with learning difficulties in Arabic and mathematics subjects. The importance of this research is represented in the sample that has been a major focus of educational institutions worldwide, and the findings it implies on the learning process; students' achievement and comprehension levels; and on shaping students positive attitudes. Pre and post diagnostic tests in Arabic and mathematics were administered to 20 students with learning difficulties in grades 2 to 4 . The tests were classified into three levels, according to the curriculum level in grades two to four. An enriching program was integrated, consisting of several interactive activities that can be achieved with the use of smartboards. The program was accomplished throughout eight weeks that included sixteen sessions (two weekly sessions for each student).

Al-Shizawi discussed the effectiveness of digital story on raising the attention of mentally disabled grade 4 students (who are able to learn in special education classes) in Science and Environment Subject from the perspective of teachers in Altrbia Alfkria School in Oman. [26] points out that the learning process of students with mental disability requires special attention in all stages. The knowledge that students gain usually depends on their attention, as well as the important role of the digital story in improving student's attention level due to the integration of media and attractive stimulus. The researcher considered the use of digital story as supportive for students with mental disabilities because it attracts their attention. The current research draws teachers' attention to not abide by the old traditional methods of teaching students with mental disabilities, and to try to take advantage of modern technology in education. The goal of the research is to identify the factors influencing the attention of students with mental disabilities, and to set specifications to be followed when designing digital stories for this category. The research is based on the hypothesis that there are positive differences between the use of digital story and traditional teaching methods to teach Science and Environment subject for students with mental disabilities. The research results stress the importance of integrating digital story in increased teacher attention; interacting with stimulus that contribute to attention upgrading; and remembering aspects that help to finish tasks. Further, the research identifies standards and specifications to design a digital story for this category of students.

The studies conducted in the Omani context show general positive outcomes of AT on the academic level of students with disabilities, using various devices and applications. Studies also point out that students are able to learn regardless of their disability. The current study is conducted to explore the status of using AT in the learning of students with disabilities at the Omani Sultan Qaboos University. 


\section{Study Objective}

This study was conducted to explore the status of using AT in the learning of students with disabilities at Sultan Qaboos University. The study aims to investigate students with disabilities' perspectives towards using AT in their learning, with particular reference to gender and self-esteem.

\section{Study Questions}

1. To what extent is AT used in students with disabilities' learning?

2. Are there any statistically significant differences at $(\alpha=0.05)$ between the means of students' responses related to gender in terms of their use of AT?

3. How does students' use of AT in learning relate to their self-esteem?

\section{Study Importance}

The study is important because it identifies the uses of assistive technology by students with disabilities for the research environment. There is a dearth of studies about these uses in the country's context in general, and at the institutional level in particular. In addition, results from this study will be generalized to to include all SQU colleges, thus, offering a guide for the decision-making process in the future.

\section{Research Method}

This research used a descriptive approach for analyzing students with disabilities' perspectives toward using AT in their learning; including learning achievement, learning motivation, sharing and communication, critical thinking, and self-esteem perspectives. This research is conducted in Sultan Qaboos University as a case study, focusing on students with disabilities studying different Bachelor level programs.

\subsection{Study Community and Sample}

The total student population is 72 as in Fall 2019 semester, with 36 male and 36 female students representing all colleges- except College of Nursing.

The study sample consists of 60 students; 27 males, and 33 females, representing $83 \%$ of the total population. The description of the study sample is shown in Table 3.

Table 3. Study sample

\begin{tabular}{|l|l|l|l|}
\hline Variables & Type & Number & $\%$ \\
\hline Gender & Male & 27 & 45.0 \\
\hline & Female & 33 & 55.0 \\
\hline $\begin{array}{l}\text { Type of } \\
\text { disability }\end{array}$ & poor eyesight & 18 & 30.0 \\
\hline & blind & 26 & 43.3 \\
\hline & $\begin{array}{l}\text { impaired } \\
\text { mobility }\end{array}$ & 15 & 25.0 \\
\hline & poor hearing & 1 & 1.7 \\
\hline Colleges & education & 2 & 3.3 \\
\hline & $\begin{array}{l}\text { economics and } \\
\text { political sciences }\end{array}$ & 2 & 3.3 \\
\hline & law & 3 & 5.0 \\
\hline & Art & 51 & 85.0 \\
\hline & science & 2 & 3.3 \\
\hline $\begin{array}{l}\text { Skills of using } \\
\text { Technology }\end{array}$ & low level & 12 & 20.0 \\
\hline & $\begin{array}{l}\text { intermediate } \\
\text { level }\end{array}$ & 34 & 56.7 \\
\hline & high level & 14 & 23.3 \\
\hline & Total & 60 & $100 \%$ \\
\hline
\end{tabular}

\subsection{Questionnaire Validity and Reliability}

The researchers ventured to develop such a tool based on the findings and extensive review of literature [27] [28] [29] [30]. The researchers developed a list representing the factors affecting students with disabilities use of assistive technology at Sultan Qaboos University. The final version of the tool lists 54 items covering 4 major domains of learning effectiveness using assistive technology: academic achievement, motivation, sharing and communication, and critical thinking. On a likert scale of 1-5, respondents were asked to rate the extent to which learning effectiveness is achieved.

Additionally the questionnaire includes 5 demographic variables (gender, type of disability, colleges study year, province, and skills of using technology) related to the respondents.

To determine the validity of the questionnaire, it was tested by nine experts who assured its validity. Also, to assure its reliability, a random sample of 19 students were selected to respond to it, and the Chronbach-Alpha was found to be 0.986 on the total items; 0.896 for academic achievement, 0.930 for motivation, and 0.897 for sharing and communication. 
The result of Chronbach's Alpha is highly statistically accepted as shown in Table 4.

Table 4. The result of Chronbach's Alpha

\begin{tabular}{|l|l|l|l|}
\hline Domains & Items & $\begin{array}{l}\text { Number } \\
\text { of item }\end{array}$ & $\begin{array}{l}\text { Chronbach's } \\
\text { Alpha }\end{array}$ \\
\hline $\begin{array}{l}\text { Academic } \\
\text { Achievement }\end{array}$ & $1-15$ & 15 & 0.896 \\
\hline Motivation and & $16-26$ & 11 & 0.930 \\
\hline $\begin{array}{l}\text { Sharing } \\
\text { Communication }\end{array}$ & $27-36$ & 10 & 0.897 \\
\hline Critical thinking & $37-54$ & 18 & 0.970 \\
\hline Total & $1-54$ & 54 & 0.986 \\
\hline
\end{tabular}

\subsection{Data Collection}

The tool was distributed electronically to the study sample by a research assistant. The data was totally collected between April to June 2019.

\section{Research Findings}

This section presents data analysis of the study questions. It shows SQU students' perspectives towards AT. It also provides information on the statistical treatments, and susequent results.

\subsection{First Research Question}

Since this study adopted a descriptive approach, the means and standard deviations were calculated for each domain to represent respondents' point of view regarding assistive technology use in learning as shown in Table 5.

Table 5. Means and standard deviation (SD) of respondent in each domain

\begin{tabular}{|l|c|c|}
\hline Domain & Mean & SD \\
\hline Learning achievement & 3.83 & .642 \\
\hline Learning motivation & 3.90 & .801 \\
\hline Sharing and communication & 4.09 & .666 \\
\hline Critical thinking & 3.82 & .775 \\
\hline Total & 3.93 & .717 \\
\hline
\end{tabular}

Findings of the first question shown in Table 5 reveal that the mean of using AT in learning is 3.93, which is higher than the average level of usage at the theoretical mean of 3.00 , as a criterion to judge the result. The mean 4.09 is the highest mean of using AT in learning, followe by sharing and communication mean value of 4.09 , learning motivation mean value of 3.90 , learning achievement mean value of 3.83 and finally, critical thinking is rated at 3.82 .

Findings of students' responses show that students belive that AT allows them to develop their abilities to search for new information despite their disability (4.00). Additionally, AT gives students with disabilities more opportunities to collaborate and share ideas and information with their colleagues (4.00). In terms of learning motivation, AT increases students with disabilities self-confidence towards completing their academic tasks despite their disability (4.05), and makes learning more enjoyable to them (3.98). In sharing and communication domain, the students with disabilities indicate that AT develops their skills to search information online (4.23), and offers them the opportunity to participate effectively with others when completing academic tasks electronically (3.97). With regards to critical thinking domain, students perceive that AT allows them to develop their senses of questioning and investigating (4.25), in addition to helping them become more creative (4.05), and develop problem-solving skills (4.03).

\subsection{Second and Third Research Questions}

The second question results are shown in Table 6 . Findings shown in Table 6 indicate no statistically significant differences at $(\alpha=0.05)$ between the means of students' responses related to gender in all domains. This reflects the agreement among all responses related to perspectives towards AT in learning. With regard to students' responses toward self-esteem, the Rosenberg' Self-Esteem Scale was implemented, and the results show that students with disabilities responses are over average in self-esteem scale, with a total mean of 4.30 .

In order to investigate the third research question i.e. relationship between students' responses to AT in learning and self-esteem scale, a Pearson correlation test was conducted, as shown in Table 7.

Findings in Table 7 show a statistically significant correlation $(\alpha=0.01)$ between learning achievement and learning motivation ( $\mathrm{r}=0.683$ ), between learning achievement and sharing and communication $(\mathrm{r}=0.699)$, and learning achievement and critical thinking $(\mathrm{r}=0.567)$. Moreover, there is a statistically significant correlation $(\alpha=0.01)$ between learning motivation and SH (r=0.675), and between learning motivation and crtical thinking ( $\mathrm{r}=0.638)$. 
Table 6. T-test results

\begin{tabular}{|l|l|l|l|l|l|l|l|}
\hline Domain & Gender & No & Means & SD & df & t-test & $\begin{array}{l}\text { Significant } \\
\text { (2-tailed) }\end{array}$ \\
\hline $\begin{array}{l}\text { Learning } \\
\text { achievement }\end{array}$ & male & 27 & 3.8148 & .60682 & 58 & .200 & .842 \\
\hline & femal & 33 & 3.8485 & .67875 & & & \\
\hline $\begin{array}{l}\text { Learning } \\
\text { motivation }\end{array}$ & male & 27 & 4.0370 & .66399 & 58 & 1.202 & .234 \\
\hline $\begin{array}{l}\text { Sharing and } \\
\text { communication }\end{array}$ & femal & 33 & 3.7879 & .89294 & & & \\
\hline & male & 27 & 4.0741 & .64605 & 58 & .183 & .855 \\
\hline Critical thinking & male & 33 & 4.1061 & .69324 & & & \\
\hline & femal & 33 & 3.9444 & .65535 & 58 & 1.158 & .252 \\
\hline total & male & 27 & 4.7121 & .85723 & & & \\
\hline & FEMAL & 33 & 3.0185 & .65752 & 58 & .911 & .366 \\
\hline & & & & & & & \\
\hline
\end{tabular}

Table 7. Result of pearson correlation coefficient to student responses

\begin{tabular}{|c|c|c|c|c|c|c|}
\hline \multicolumn{2}{|l|}{ Domains } & \begin{tabular}{|l}
$\begin{array}{l}\text { Learning } \\
\text { achievement }\end{array}$ \\
\end{tabular} & Learning motivation & $\begin{array}{l}\text { Sharing and } \\
\text { communicati } \\
\text { on }\end{array}$ & Critical thinking & Self-esteem \\
\hline \multirow{2}{*}{$\begin{array}{l}\text { Learning } \\
\text { achievement }\end{array}$} & \begin{tabular}{|l|} 
Pearson \\
Correlation
\end{tabular} & 1 & $.683^{* *}$ & $.699^{* *}$ & $.567^{* *}$ & $.289^{*}$ \\
\hline & $\begin{array}{l}\begin{array}{l}\text { Sig. } \\
\text { tailed })\end{array} \\
\end{array}$ & & .000 & .000 & .000 & .025 \\
\hline \multirow{2}{*}{$\begin{array}{l}\text { Learning } \\
\text { motivation }\end{array}$} & $\begin{array}{l}\text { Pearson } \\
\text { Correlation } \\
\end{array}$ & $.683^{* *}$ & 1 & $.675^{* *}$ & $.638^{* *}$ & .223 \\
\hline & $\begin{array}{l}\text { Sig. } \\
\text { tailed })\end{array}$ & .000 & & .000 & .000 & .086 \\
\hline \multirow[t]{2}{*}{$\begin{array}{l}\begin{array}{l}\text { Sharing and } \\
\text { communication }\end{array} \\
\end{array}$} & \begin{tabular}{|l|} 
Pearson \\
Correlation
\end{tabular} & $.699^{* *}$ & $.675^{* *}$ & 1 & $.631^{* *}$ & .145 \\
\hline & $\begin{array}{ll}\text { Sig. } \\
\text { tailed })\end{array}$ & .000 & .000 & & .000 & .271 \\
\hline \multirow{2}{*}{ Critical thinking } & $\begin{array}{l}\text { Pearson } \\
\text { Correlation }\end{array}$ & $.567^{* *}$ & $.638^{* *}$ & $.631^{* *}$ & $\mid 1$ & .092 \\
\hline & $\begin{array}{l}\begin{array}{l}\text { Sig. } \\
\text { tailed })\end{array} \\
\end{array}$ & .000 & .000 & .000 & & .483 \\
\hline \multirow{2}{*}{ Self-esteem } & $\begin{array}{l}\text { Pearson } \\
\text { Correlation }\end{array}$ & $.289^{*}$ & .223 & .145 & .092 & 1 \\
\hline & \begin{tabular}{|ll}
$\begin{array}{l}\text { Sig. } \\
\text { tailed })\end{array}$ & $(2-$ \\
\end{tabular} & .025 & .086 & .271 & .483 & \\
\hline
\end{tabular}

** Correlation is significant at the 0.01 level (2-tailed)

* Correlation is significant at the 0.05 level (2-tailed) 
Findings also point out a statistically significant correlation $(\alpha=0.01)$ between sharing and communication and critical thinking $(\mathrm{r}=0.631)$. Moreover, the findings indicate no statistically significant correlation between student responses to the study domains and self-esteem scale total mean at all domains, except between learning achievement and self-esteem $(r=0.289)$ at $(\alpha=0.05)$.

\section{Discussion}

This study was conducted to explore the status of using Assistive Technology in the learning of students with disabilities at the Omani Sultan Qaboos University. Findings of the first research question show that SQU students with disabilities percieve their use of AT in learning as generally high, specifically as in the means of sharing and communication, learning motivation, and critical thinking. These uses can be attributed to the technological facilities provided for these students such as ease of accessibility from inside and outside the campus. These findings are substantiated by the research findings in [8], [3] and Burgstahler (2003; as cite in [9]), and [10]. In addition, findings show that students perceive AT as a tool to develop their abilities to search new information and offer them the opportunity to collaborate and share information with their colleagues. They believe that AT increases their self-confidence towards completing their academic tasks despite their disabilities, and makes learning enjoyable to them. It allows them to advance in their ability to question and investigate, and develop their creatity. The positive responses and perceptions of using AT in students with disabilities learning are also echoed in other research [17] [18] [19] [31].

The statistical significant correlations between most of the study domains show the interrelated effect and relations among these domains. Research corroborates these findings. For example, [9], [10] and [11] studies show that AT facilitates the accomplishment of classroom discussions and enables students to be more independent. However, this study findings contradict the results of [13] in that students with disabilities are highly satisfied with their selfesteem, as no statistically significant correlation was found between students' responses to the study domains and self-esteem scale total mean at all domains, except between learning achievement and self-esteem. It is notable that, despite the fact that using AT by students with disabilities has a positive influence on the educational domains in terms of their achievement and critical thinking, it negatively affects the self-esteem domain due to the social and psychological isolation, a side effect of technology use even for normal students. In addition, these findings can be interpreted by the need to train teachers who are not familiar with the benefits of assistive technology for students with disabilities as proved by [10].

\section{Conclusion and Recommendations}

The results of this study indicate positive perceptions of students with disabilities towards AT. They perceive it as a tool developing their abilities to search new information; providing them with opportunities to collaborate and share ideas and information with their colleagues; motivating them to learn; and allowing them to develop their creativity and problem-solving skills. However, the study found that AT negatively impacts students with disabilities' learning self-esteem.

These results remain preliminary as they investigate only one aspect i.e. the student's aspect, and the need arises to elaborate on by looking into other stakeholders' aspects; namely the faculty members and other involved parties. Therefore the study suggests that SQU may need to train teachers who are not familiar with the benefits of assistive technology on students with disabilities to avoid any passive impact of AT on their students' learning. In the field of research, the universal principles for teaching students with disabilities known as UDL should be investigated at SQU.

\section{References}

[1] M. Al-Sukran, "Toward Culture Informed to Deal with the Disabled", Modern Education Journal, 5(16), Egypt, 2012, pp. 13-28.

[2] A. Al-Hosawi, "Barriers to using special educational techniques in teaching mentally retarded students as perceived by their teachers in Riyadh", $1^{\text {st }}$ Scientific Conference on Special Education, July 2007, Vol. 2, Banha University, Egypt, 2007, pp. 15-16.

[3] E. Al-Khafaf, E-Learning, Scientific Isar Publishing, Amman, Jordan, 2018.

[4] H. Cevahir, and M. Özdemir, "Mobile Learning Researches towards Individuals with Disabilities: A Content Analysis between 2005 and 2015", IJODE, 2(1), 2015, pp. 31-40. 
[5] I.V. Sancar, S.B, Tozkoparan, and H.F. Odabasi, "Use of mobile technologies in special education: A content analysis", Journal of Education and Special Education Technology, 3(1), 2017. pp. 1-12.

[6] A. AlHayajna, "The role of e-learning systems in addressing educational problems in the Arab region", the Children and Youth Conference in Middle Eastern and North African Cities: Addressing the Challenges of Education, Dubai, May 16-18, 2005, 2005, pp. 9-24.

[7] T. Cavanaugh, "The need for assistive technology in educational technology", Educational Technology Review, 10(1), 2002, pp. 1-5.

[8] C. Colarusso, "The evolution of paternal identity in late adulthood", Journal of American Psychological Association, 53(1), 2005, pp. 51-81.

[9] G. Alnahdi, "Assistive technology in special education and the universal design for learning", The Turkish Online Journal of Educational Technology, 13(2), 2015, pp. 18-23.

[10] A. Ahmed, "Perceptions of Using Assistive Technology for Students with Disabilities in the Classroom", International Journal of Special Education, 33(1), 2018, pp. 129-139.

[11] C. Semaan, and E. Kiwan,"Impact of "kubbu" on the Academic Achievement and Motivation of $4^{\text {th }}$ Grade Students with disabilities", International Journal of Innovation and Research in Educational Sciences, 4(6), 2018, pp. 683-689.

[12] M. Rosenberg, Society and the adolescent self-image, NJ: Princeton University Press, Princeton, 1965.

[13] A. Abu Daoud, and J. Al Khateeb, "Life Satisfaction and its Relationship to Self Determination Skills and Hope in Adolescents with Disabilities in Jordan", Al najah Journal for Research, 31(11), 2017, pp. 1889-1910.

[14] Ministry of Social Development, "A brief report on the services provided to persons with disabilities in the Sultanate", General Directorate of Social Welfare, Oman, 2010.

[15] W. Al-Ani, "Alternative education needs in Oman: accommodating learning diversity and meeting market demand", International Journal of Adolescence and Youth, 22(3), 2017, pp. 322-336, DOI: 10.1080/02673843.2016.1179204.

[16] I. Alqaryouti, "Inclusion the Students with disabilities in Higher Education in Oman", International Journal for Cross-Disciplinary Subjects in Education (IJCDSE), 1(4), 2010, pp. 216-222.

[17] A. Al Musawi, and A. Abdelraheem, "E-learning at Sultan Qaboos University: Status and Future", British Journal of Educational Technology, 35(3), British Educational Communications and Technology Agency, UK, 2004, pp. 363-367.

[18] S. Issan, and W. Al-Ani," The reality of e-learning from the viewpoint of students of the College of Education at Sultan Qaboos University", Dirasat Journal of Educational Sciences, 34(2), Jordan, 2007, pp. 341356.

[19] A. Al Musawi, "Use of Social Media in Technology Enhanced Learning", In Al Shahrahi, K. and Ally, M. (Ed.) Transforming Education in the Gulf Region: Emerging Learning Technologies and Innovative Pedagogy for the 21st Century, 2016, pp. 126-138, Routledge Research in Education.

[20] M. Al-Rabeei, and M. Al-Oufi, "The role of distance education using modern education techniques in achieving some of the education goals of learners with disabilities", International Conference on Distance Education: Towards New Horizons (ICODE), SQU and Ministry of Higher Education, 27-9/3/2006, pp. 127155, Oman.

[21] S. El-Shourbagi, "Parental involvement in inclusive classrooms for students with learning disabilities at Omani schools as perceives by teachers", Journal of Psychology Cognition 2(2), 2017, pp. 133-137.

[22] I. Al Qaryouti, and J. Al Shukaili, "Sultan Qaboos University Students' Attitudes towards Inclusion of Their Peers with Disabilities", Journal of Educational and Psychological Studies Sultan Qaboos University, 9(2), 2015, pp. 262-274.

[23] M. Ammar, "Challenges of students with disabilities using e-learning from the viewpoint of teachers of basic education in the Sultanate of Oman", Paper presented at the $6^{\text {th }}$ International Conference on Information and Communication Technology and Connectivity (ICTA2017), 19-21 December 2017, Arab Organization for Education, Culture and Science and SQU, Oman.

[24] S. Al Alawi, "Effectiveness of a teaching program based on the inverted class strategy via smartphones in academic achievement in the subject of social studies for blind students in the eighth grade in the Sultanate of Oman", Paper presented at the $6^{\text {th }}$ International Conference on Information and Communication Technology and Connectivity (ICTA2017), 19-21 
December 2017, Arab Organization for Education, Culture and Science and SQU, Oman.

[25] R. Al-Aisari, and S. Al-Balushi, "Designing an interactive module on the human body via tablets for people with hearing disabilities". Paper presented at the $6^{\text {th }}$ International Conference on Information and Communication Technology and Connectivity (ICTA2017), 19-21 December 2017, Arab Organization for Education, Culture and Science and SQU, Oman.

[26] M. Al-Shizawi, "The effectiveness of using digital story to improve attention level in teaching science and environment for students with mental disabilities (who are able to learn) in the fourth grade from the viewpoint of teachers at the School of Intellectual Education in the Sultanate of Oman", Paper presented at the $6^{\text {th }}$ International Conference on Information and Communication Technology and Connectivity (ICTA2017), 19-21 December 2017, Arab Organization for Education, Culture and Science and SQU, Oman.

[27] C. Gerrard, "Virtual learning environments enhancing the learning experience for students with disabilities", Campus Wide Information systems, 24(3), 2007, pp. 199-206.

[28] E.M. Thomas, "Using assistive technology: the experiences of students with disabilities in a distance learning university", Ed.D. Dissertation, Queen's University Belfast, (ProQuest document ID: 1761445231), 2008.

[29] F.D. Guevara, "Assistive technology as a cognitive developmental tool for students with learning disabilities using 2D and 3D computer object", $\mathrm{PhD}$ Dissertation, University of Texas, (ProQuest document ID: 1796188771), 2009.

[30] W. Al-Ani, “The Blended Learning Approach Using Moodle and Students' Achievement at Sultan Qaboos University in Oman", Journal of Education and Learning, 2(3), 2013, pp. 96-110.

[31] M. Al-Ani, F. Al-Hanai, and N. Al-Yaqoobi, "The effect of the smart board on the academic achievement of students with learning difficulties for basic education (Al Kawthar School as an example)", Paper presented at the $6^{\text {th }}$ International Conference on Information and Communication Technology and Connectivity (ICTA2017), 19-21 December 2017, Arab Organization for Education, Culture and Science and SQU, Oman.

\section{Acknowledgements}

The research team expresses their gratitude to the College of Education at SQU for the generous grant (IG/EDU/DEFA/19/01) awarded to them. Such institutional effort makes this research paper possible. 